\title{
A imprensa católica a serviço da reforma ultramontana: o caso do Mensageiro do Coração de Jesus
}

\author{
The Catholic press in the service of ultramontane reform: the case of \\ the Messenger of the Heart of Jesus
}

\author{
Ana Rosa Cloclet da Silva ${ }^{1}$ \\ Lais da Silva Lourenço ${ }^{2}$
}

RESUMO

O presente artigo visa analisar o periódico jesuíta Mensageiro do Coração de Jesus, entre 1896 e 1900. Inserido no contexto das reformas ultramontanas, a normatização clerical, a afirmação da infalibilidade papal e a defesa da subordinação da Igreja à Santa Sé passaram a ser difundidas por diversos atores, tanto leigos, quanto clérigos. É nesse momento que os jesuítas retornam ao Brasil, estabelecendo-se na então Vila de Itú, no ano de 1856. Elaborando estratégias de fixação na soiedade local, tais clérigos atuaram para além da esfera religiosa. Nessa perspectiva, um dos campos de sua ação fora a imprensa, através do Mensageiro do Coração de Jesus, periódico cuja análise nos permite compreender as relações entre imprensa, ultramontanismo e atuação jesuítica no Brasil do fim do século XIX e início do XX. Através da análise desta fonte, o presente artigo busca averiguar a natureza do projeto de modernidade elaborado por estes clérigos, articuladamente a outros projetos em voga: como o liberal e o projeto da Igreja, de moldes tridentinos. Como contribuição geral, busca-se colaborar na compreensão dos rumos assumidos pelas reformas ultramontanas no Brasil durante o período analisado, revelador da especificidade do processo de secularização em curso.

Palavras-chave: Modernidade. Secularização. Religião. Política. Jesuítas. Imprensa católica.

\section{ABSTRACT}

This article analyzes the periodical Jesuit Messenger of the Heart of Jesus, between 1896 and 1900 . In the context of ultramontane reforms, clerical normalization, the affirmation of papal infallibility and the defense of the subordination of the Church to the Vatican, began to be spread by various actors, both lay and clergy. At that moment the Jesuits return to Brazil, establishing themselves in the Village of Itú, in 1856. By elaborating strategies of fixation in the local society, such clerics acted beyond the religious sphere. In this perspective, one of the fields of his action was the press, through the Messenger of the Heart of Jesus, a journal whose analysis allows us to understand the relations between press, ultramontanism and Jesuit

\footnotetext{
${ }^{1}$ Doutora em História (UNICAMP-2000).Docente da Faculdade de História do Programa de Pós-Graduação Stricto Sensu em Ciências da Religião-PUC-Campinas. e-mail: anacloclet@gmail.com

${ }^{2}$ Mestre pelo programa de Ciências da Religião da PUC- Campinas. e-mail: lais.hist@gmail.com
} 
action in Brazil in the late nineteenth and early twentieth centuries. Through the analysis of this source, the present article seeks to identify the nature of the project of modernity elaborated by these clerics, in articulation with other projects in vogue: like the liberal and the project of the Church, of tridentine molds. As a general contribution, he collaborates in the understanding of the ultramontane reforms in Brazil during the analyzed period, which resulted in a singular process of secularization.

Keyword: Modernity. Secularization. Religion. Policy. Jesuits. Catholic press

\section{Introdução}

Nos últimos anos, acompanhando a complexidade instaurada na configuração do campo religioso ocidental contemporâneo, pesquisadores de diferentes áreas são levados a revisitar temáticas clássicas dos estudos de religião, bem como avançar sobre renovados enfoques sobre o objeto. Reconhecendo que a emergência de uma esfera pública secular não, necessariamente, deu-se pela perda das funções moralizadora e integradora da religião, com seu deslocamento para a esfera da autonomia individual (HAUPT, 2008), emergem reflexões teóricas preocupadas em dissociar as reconstruções analíticas eurocentristas de uma teoria geral da modernidade, indagando sobre outras experiências - "não ocidentais" e "não seculares" (CASANOVA, 2006, p. 10) - capazes de revisar, quer o problema teórico das relações entre religião e esfera pública, quer suas implicações para a construção de uma ética política, que em determinados casos "não adveio senão da própria religião" (PIRES, 2012, p. 33).

Sob tal perspectiva, pesquisadores de diferentes áreas concordam que a crítica da religião (genericamente designada anticlericalismo) e a posterior separação institucional entre a Igreja e o Estado não expressou um percurso monolítico rumo a uma secularização concebida como "processo caracterizado pelo desaparecimento dos laços religiosos, pelo enfraquecimento das relações com a transcendência e pela diminuição das expectativas de uma vida pós-morte" (SOUZA, 2010, p. 43-57), mediante o qual houve a progressiva substituição do poder religioso pelo temporal. Ao contrário disso, do ponto de vista de suas manifestações concretas, o fenômeno da secularização traduziu um processo marcado pela concorrência entre diferentes propostas de modernidade, de cujos embates produziram-se combinações complexas entre a perda do domínio dos grandes sistemas religiosos e as reconfigurações da religião por sociedades que continuaram reivindicando-na como condição para pensarem-se a si mesmas como autônomas (HERVIEU-LÉGER, 2004, p. 37).

Sob tal enfoque, é possível situar a experiência brasileira ao lado daquelas outras experiências socioculturais - europeias e extra-europeias - associadas ao advento da modernidade, indagando acerca das condições históricas sob as quais produziu-se a "autonomização" entre as esferas política e religiosa, em tal caso específico. 
A nosso ver, avaliar as características próprias deste movimento e, neste sentido, "avançar na determinação da natureza do processo de secularização", exige e justifica a "elaboração de aproximações de caráter histórico" (DI STEFANO, 2011, p. 1), que permitam identificar as relações que os sistemas religiosos mantém com o tipo de sociedade ou cultura que os explicam (JULIÁ, 1976, p. 108). Conforme consenso que vem sendo forjado entre pesquisadores do tema, não considerar a historicidade do fenômeno religioso pode gerar anacronismos, prejudicando a compreensão e a validade de tais estudos, uma vez que "as religiões se desenvolvem em situações historicamente dadas", sendo, portanto, históricas. (LONDOÑO, 2013, p. 221; GRESCHAT, 2005)

Sob tal perspectiva, o presente artigo visa analisar as manifestações institucionais e discursivas do fenômeno religioso num contexto específico: aquele que reporta ao retorno dos jesuítas ao Brasil, na segunda metade do século XIX. Especificamente, busca analisar a trajetória dos clérigos jesuítas instalados na então Vila de Itú, entre 1856 e 1918, quando transferem-se para São Paulo. Antes um dos principais redutos da formação regalista de clérigos - como do padre Diogo Antônio Feijó -, Itú tornou-se um dos locais de fixação dos representantes da Ordem desde seu retorno ao Brasil.

Vale frisar que, inseridos num contexto de profundas reconfigurações nas relações entre Igreja católica e Estado Imperial - identificado como o processo de "romanização"3 -, a conjuntura histórica daquele momento em muito se diferenciava da existente quando da expulsão da Companhia de Jesus dos domínios portugueses, decretada pelo Marquês de Pombal em 1759. Isto porque, seguindo as diretrizes provindas de Roma e filtradas pelo bispado nacional à luz das contingências locais, desde 1844, observou-se a perda de legitimidade política dos clérigos de tradição galicano-jansenistas - hegemônicos em termos da política nacional durante toda a primeira metade do século XIX -, afirmando-se a vertente ultramontana da secularização. Sob esta, defendeu-se a autoridade de uma Igreja institucional e hierárquica, diretamente subordinada a Roma e cada vez mais dependente de padres estrangeiros pertencentes às congregações e ordens missionárias, enviados ao Brasil com a função de "controlar a doutrina, a fé, as instituições e a educação do clero e laicato".

Formuladas e executadas no âmbito do papado de Pio $\mathrm{IX}^{4}$, o "projeto de modernidade tridentino" (PRODI, 2010) tendeu, deste então, a afirmar um modelo de Igreja apoiado no dogma da infalibilidade do poder papal e na defesa da sua identidade como instituição, colaborando para a separação jurídica e institucional entre Igreja e Estado no Brasil,

\footnotetext{
${ }^{3}$ O termo "romanização" chegou ao Brasil a partir da tradução do livro prefaciado por Rui Barbosa, O Papa e o Concílio, de Döllinger, publicado no Brasil em 1877. Nesta, o teólogo liberal de Munique protestava contra o crescente absolutismo papal e o reavivamento da teologia escolástica, sendo marco das manifestações contrárias à definição do dogma da infalibilidade papal. (SANTIROCHI, 2010)

${ }^{4}$ Do ponto de vista de sua orientação, tais reformas foram referenciadas, a partir de agosto de 1864, em dois documentos emitidos pelo papa Pio IX: a Encíclica Quanta Cura - que deveria oferecer uma síntese dos erros relacionados à sociedade moderna e, especialmente, à questão da liberdade de consciência -, seguida pelo Syllabus - uma lista contendo tais erros, representando a resposta ortodoxa da Igreja católica à sociedade contemporânea.
} 
finalmente consagrada pela Constituição de 1891. Nestes termos, a atuação ultramontana nos permite antever a Igreja como agente da secularização, pois: "La defensa de los 'derechos de la Iglesia' implica que Iglesia y Estado son dos realidades no sólo distintas, sino también necesariamente diferentes" (DI STEFANO, 2008).

Dessa forma, longe de expressar um entrave à construção de uma sociedade laica, tal processo expressou uma via específica da secularização, profundamente religiosa, reprisada em outros contextos latinoamericanos e mesmo europeus. Embora inicialmente sustentado pelo episcopado nacional, tal movimento mobilizou diversos instrumentos e atores, ${ }^{5}$ que atuaram a partir das esferas de representação política e do ensino superior, ${ }^{6}$ além das vias não institucionais. Dentre estas, a imprensa periódica - que exerceu inegável papel na transformação dos espaços públicos e na emergência de uma opinião pública atrelada às novas ideias e formas políticas constitucionais (ANDERSON, 1989) - tornou-se um dos principais porta-vozes dos ideais e projetos ultramontanos, sendo vários os jornais católicos que surgiram na segunda metade do século XIX e no início do período republicano.

Nas reflexões que seguem, procuraremos analisar, dentre as estratégias de atuação dos clérigos jesuítas instalados em Itú - que incluíram a fundação do Colégio São Luís e do Apostolado da Oração - o discurso religioso impresso nas páginas do periódico Mensageiro do Coração de Jesus, editado pela Ordem no contexto em foco. Através desta fonte, busca-se compreender as articulações entre os princípios fundamentais da Ordem, as orientações provindas de Roma e as contingências locais da sociedade ituana, reconstituindo-se a dinâmica conflitiva capaz de revelar, no sentido empregado por Pierre Bourdieu (1974), as profundas e complexas relações entre o campo religioso e o político ${ }^{7}$. Da mesma forma, visa compreender como o aspecto doutrinário, baseado na tradição da Ordem, fora moldado e influenciado pelos referenciais de modernidade em voga, representativos de projetos alternativos atrelados aos ideais de progresso, civilização, ciência e educação, que os jesuítas não puderam ignorar.

\footnotetext{
${ }^{5}$ Dentre os quais: - clérigos de diferentes formações; leigos com orientações intelectuais também distintas; ordens regulares provindas de diferentes países; irmandades leigas; confrarias; aspectos da religiosidade popular profundamente arraigados na sociedade brasileira; etc. De tal forma que o próprio conceito de "romanização" - correntemente utilizado pela historiografia, para designar o conjunto das reformas ultramontanas levadas a cabo entre meados do século XIX e as três primeiras décadas do século XX - revela-se incapaz de "englobar a complexidade do processo histórico ao qual se refere". (SANTIROCCHI, 2010, p. 32)

${ }^{6}$ As faculdades foram alvo de um forte movimento de renovação filosófica e teológica inspirado nas bases tomista e escolaticista, banidas pelas reformas pombalinas Exemplo disso foi a renovação ocorrida na Faculdade de Direito de Olinda, onde foi professor José Soriano de Souza (1833-1895), um dos principais expoentes do ultramontanismo leigo, e onde também estudou Cândido Mendes de Almeida, jurista e defensor da reforma ultramontana, preocupado em elaborar as bases do Direito Eclesiástico no Brasil, separado do Direito Civil. (MARTINS, 2011).

${ }^{7}$ No sentido empregado pela Nova História política, cujo referencial teórico subsidia esta análise, trata-se de compreender o político em sentido amplo, mutável e capilarizada pelo tecido social, através de mecanismos e estratégias desdobrados na sua dimensão material e simbólica. (RÉMOND, 1999).
} 


\section{A impresa como estratégia de atuação jesuita}

Apesar de ser essencialmente moderna, a imprensa fora utilizada para divulgar e afirmar determinadas concepções muitas vezes tradicionais e contrárias a âmbitos específicos da modernidade. Nesse sentido, a modernidade fornecera ferramentas para sua própria crítica e para debates sobre as diversas transformações verificadas naquele momento. Estes foram veiculados por todo o Brasil, sendo capazes de interferir nos esquemas de pensamento dos indivíduos e legitimar determinadas posições assumidas tanto por clérigos quanto por leigos.

Deve-se considerar que a construção do fato jornalístico interfere não apenas em elementos subjetivos daqueles que os produz, mas, também, refletem os interesses dos jornais que os veicula (CAPELATO, 1988). Nesse sentido, o discurso veiculados pela imprensa periódica legitima determinadas visões de mundo e desqualifica outras, constituindo-se na "relação entre formações discursivas e ideológicas" (ORLANDI, 1983, p. 216). Na perspectiva de Orlandi, os lugares do locutor e do ouvinte se definem um pelo outro, e, em sua relação, definem o espaço da discursividade. (ORLANDI, 1983, p. 214). Pautados em seus contextos imediatos de enunciação e guardando relação com o contexto histórico que os informa (ORLANDI, 1983, p. 214), os discursos podem, assim, ser concebidos como resultado de "representações que indivíduos ou grupos constroem sobre o mundo em que vivem, pautados, para tanto, naquilo que viveram no passado e no que esperam viver em um futuro próximo ou até mesmo longínquo. (CHARTIER apud PETERS, 2015, p. 96)

Exemplo disso, como demonstra Anderson, é que os periódicos foram poderosos atores na construção da modernidade política, incluindo a legitimação da ideia de nação: "[...] a convergência do capitalismo e da tecnologia de imprensa sobre a fatal diversidade da linguagem humana criou a possibilidade de uma nova forma de comunidade imaginada, a qual, em sua morfologia básica, montou o cenário para a nação moderna." (ANDERSON, 2008, p. 82).

Nesse sentido, a imprensa se mostra responsável pelo forjamento de uma forma específica de sociabilidade, enquanto espaço de circulação e debate entre vozes públicas acerca de determinadas questões, além da formação de um vocabulário capaz de remeter às novas formas de organização política. Sobre essa questão, Morel afirma que:

[...] não nos parece possível compreender a imprensa, mesmo a periódica, isolada da sociedade. A imprensa influenciava e era influenciada por vozes, falas e gestos não escritos, em via de mão dupla, numa complexa 
teia de circulação, recepção e retransmissão de conteúdos que ultrapassavam o espaço impresso. (MOREL; BARROS, 2003, p. 103).

A partir da imprensa emerge a opinião pública, que como demonstra Morel, "remete a um vocabulário político que desempenhou papel de destaque na constituição dos espaços públicos e de uma nova legitimidade nas sociedades ocidentais a partir de meados do século XVIII", com capacidade "para influir nos negócios públicos, ultrapassando os limites do julgamento privado." (MOREL, 2008, p. 33).

No Brasil, apesar da existência da imprensa remontar à instalação da Corte no Rio de Janeiro, em 1808 - com a criação da Imprensa Régia - é somente após a independência que o número de publicações aumenta (SODRÉ, 1966), ao mesmo tempo em que periódicos "polêmicos" são criados (PAULA, 1973, p. 154). Nesse sentido, o surgimento e a consolidação da imprensa no Brasil vincularam-se ao surgimento da nossa modernidade política, atrelada às profundas transformações que acompanharam o processo de formação do Estado e da Nação brasileiros.

Conforme demonstrado pela recente historiografia, a frequência a tais espaços constituiu importante variável na formação político-intelectual do clero brasileiro, permitindo àqueles que não tiveram acesso à formação universitária tomar contato com as ideias e debates do século, com base nos quais elaboraram suas propostas de natureza política, mas, também, religiosa (SILVA; LOURENÇO, 2015).

Apesar desta precoce atuação na imprensa, os jornais católicos tardaram a aparecer no país, consolidando-se apenas ao final do século XIX por reação à perda de hegemonia católica e ao crescimento de outras denominações religiosas (DALMOLIN, 2012, p. 2). Naquele contexto, em que diferentes modelos de relacionamento entre Igreja e Estado disputaram a legitimidade política,

[...] a imprensa católica assume o papel de porta voz do pensamento católico frente às transformações no campo religioso e no processo de separação do Estado. [...] Dos pasquins sazonais típicos do período imperial, os jornais católicos se proliferam no período de transição para a República, ganhando periodicidade e expressão. (DALMOLIN, 2012, p. 2). 
Mediante as mudanças institucionais e jurídicas do período, clérigos e leigos defensores da subordinação da Igreja nacional à Cúria Romana lançaram não apenas críticas internas ao regalismo - modelo tradicional que reiterou o padroado até o final do Império -, mas, opuseram-se a toda e qualquer tendência associada ao liberalismo anticlerical, à maçonaria e ao pensamento filosófico científico que eram contrários aos princípios da Igreja Romana, derivando uma mescla de intolerância, coragem, caridade e espírito apologético, que teve na imprensa católica seu principal porta-voz, especialmente no período de 1870 a 1900, o qual marca a "explosão" dos periódicos católicos. 8

Se na segunda metade do século XIX a imprensa católica já se revelava instrumento capaz de viabilizar a influência da Igreja sobre a sociedade, no período republicano, efetivada a separação institucional entre Igreja e Estado, "assiste-se a uma pluralização dos títulos católicos no Brasil, que buscam expressar sua contrariedade aos chamados 'jornais liberais anticlericais"'.9 Assim, perdida a anterior condição de religião oficial do Estado, o catolicismo encontrará na imprensa um recurso fundamental no fortalecimento das relações entre a religião e a sociedade brasileira. Afinal:

\begin{abstract}
Mais do que uma miríade de iniciativas pontuais, as tipografias, editoras e livros, as revistas e os jornais católicos faziam parte de uma ampla articulação que visava assegurar a validade de uma leitura de mundo religiosa, assim como dos valores, normas e crenças que buscavam difundir em seus fiéis leitores. (ARDUINI; SILVEIRA, 2015, p. 155).
\end{abstract}

Nesse sentido, a imprensa acaba por se configurar em espaço de construção de um cenário de disputas sociais, políticas, religiosas e culturais, demonstrando ser uma fonte histórica muito profícua para a compreensão da conjuntura estudada. Diferentemente dos periódicos leigos - os quais tratavam de assuntos políticos ou sobre as perspectivas gestadas pelas novas formas de sociabilidade e representação política -, a imprensa ultramontana converteu-se em verdadeiro agente da romanização, configurando-se em peça central na luta pelo monopólio dos bens de salvação pelos representantes do catolicismo no Brasil. Na concepção dos jornais editados sob tal viés, quaisquer concepções distoantes das diretrizes romanas eram consideradas como falsa religião ou heresia, ameçando a construção de uma

\footnotetext{
${ }^{8}$ Neste período, destacam-se os periódicos: O Apóstolo (Rio de Janeiro, 1866), A Crônica Religiosa (Salvador, 1869), A Estrela (Curitiba, 1898), O Mensageiro da Fé (Salvador, 1899), adentrando ativamente o período republicano, revelando-se mesmo importante veículo na consolidação do novo regime, conforme representado pela revista Ave Maria, fundada em 1889 pelos padres da Congregação dos Missionários Filhos do Coração de Maria, até hoje em atividade. (DALMOLIN, 2012, p. 2-3)

${ }^{9}$ Um marco importante deste processo "a fundação, em 1910, do Centro de Boa Imprensa (CBI), que funcionou como uma espécie de agência de notícias e informações católicas, cedendo matérias e artigos aos periódicos católicos do país”, além das "publicações oriundas de ordens e congregações". (DALMOLIN, 2012, p. 3)
} 
sociedade harmônica e perfeita, ancorada "numa religião tida como absoluta e definitiva manifestação de Deus: o catolicismo" (CORDI, 1984, p. 3).

Divulgando discursos religiosos, especificamente, tais periódicos contém uma ideologia religiosa que constitui seu espaço de racionalidade através da linguagem (ORLANDI, 1983). Neles, Deus é locutor que fala através da voz de um suposto representante, o qual jamais ocupará o lugar de Deus, revelando um desnível fundamental na relação entre locutor e ouvinte. Nessa relação simbólica, o locutor não pode aproriar-se das palavras de Deus sem as regulações do texto sagrado, da Igreja ou das cerimônias (ORLANDI, 1983), não possuindo nenhum tipo de autonomia. Questionar o representante-locutor seria questionar a voz de Deus que fala através dele. $O$ discurso religioso é, portanto, um aspecto que distingue os fiéis dos não fiéis, delimitando a comunidade e assentando o princípio de exclusão. (ORLANDI, 1983).

Em relação á configuração deste tipo de imprensa, observa-se a criação de referenciais que associam os clérigos à aspectos específicos da modernindade. Isso porque, apesar das mensagens transmitidas, a imprensa religiosa configura-se num agente da modernização, capaz de influenciar tanto os debates essencialmente religiosos, quanto os que buscavam compreender o espaço ocupado pela Igreja naquele contexto de aceleradas transformações. Assim:

\footnotetext{
Mais do que uma miríade de iniciativas pontuais, as tipografias, editoras e livros, as revistas e os jornais católicos faziam parte de uma ampla articulação que visava assegurar a validade de uma leitura de mundo religiosa, assim como dos valores, normas e crenças que buscavam difundir em seus fiéis leitores. (ARDUINI; SILVEIRA, 2015, p. 155).
}

No caso dos periódicos ultramontanos, por exemplo, apesar da defesa da infalibilidade papal ser uma das tônicas discursivas, criava-se espaço para debates e circulação de ideais, as quais, como analisaremos adiante, entravam em conflito com as próprias diretrizes da Santa Sé, atendendo a prioridades locais e da Igreja nacional. Os periódicos religiosos, nesse âmbito, apresentavam-se enquanto meios de divulgação da fé, mas, ao mesmo tempo, de concepções políticas, morais, sociais e culturais radicadas em seus contextos históricos especíicos, sendo este um campo de atuação escolhido pelos jesuítas em diversas partes do mundo. Basenadose em dados compilados por Madureira, no ano de 1920 existiam cerca de 20 títulos de periódicos de propaganda missionária editados pelos padres da Companhia de Jesus fora do território das missões e, no mesmo ano, por volta de 49 volumes correspondentes a periódicos religiosos editados nas missões pelos jesuítas missionários espalhados por 21 países e regiões 
do mundo. (MADUREIRA, 1927). Dentre estes últimos, o Mensageiro do Coração de Jesus, figurava em cerca de 8 países, sendo editado nos idiomas e dialetos correspondentes: albanês, inglês, chinês, várias línguas indianas, malgasco, francês, árabe e, basenado-nos no caso aqui estudado, português.

Através dos territórios e das diversas línguas em que foram - e muitos ainda continuam sendo - editados, tais periódicos revelaram-se capazes de difundir concepções e interpretações da realidade, influênciando os indivíduos em nivel global. Dessa forma, a imprensa católica cumpria a função de ser, ao mesmo tempo, espaço de veiculação de ideias e valores, assim como ator histórico, empenhdo em construir novas concepções de mundo de natureza religiosa, amparados por uma base teológica refletida nas páginas dos periódicos. No caso do Mensageiro do Coração de Jesus, aqui estudado, tratava-se de difundir uma postura evangelizadora e ligada à moral, legitimando um discurso referente ao que se tomava como o padrão de "bom cristão", pois, na perspectiva do jornal, somente através dele seria possível ser respeitado pelos homens e por Deus.

\section{O Mensageiro do Coração de Jesus como instrumento dos jesuitas na sociedade ituana}

O periódico Mensageiro do Coração de Jesus configura-se num jornal católico e órgão oficial do Apostolado da Oração, impresso na Tipografia a Vapor do Apostolado do Coração de Jesus, em Itú, São Paulo. As edições eram mensais e possuíam em média 60 páginas, assinadas pelo Dr. Augusto Cesar $\mathrm{Cruz}^{10}$ e criadas pelo Padre jesuíta Bartolomeu Taddei. O criador do periódico é considerado também o fundador do movimento do Apostolado da Oração no Brasil, que no ano de 1871 iniciou-se em Itú (SCHWENGBER, 2014).

Seguindo as tendências apontadas por Dalmolin (2012), O Mensageiro enquadra-se na chamada imprensa religiosa apologética, baseando-se numa forte oposição da Igreja ao mundo secular e fundamentando-se em embates discursivos, nos quais a Igreja era defendida como a única detentora da verdade (DALMOLIN, 2012).

O discurso apologético reportava modelos de conduta e concepções idealizadas das práticas sociais. Santos, religiosos e a própria Virgem Maria servem como referência última para as práticas. Era comum a publicação de pequenas histórias pedagógicas, permeadas pelas

\footnotetext{
${ }^{10}$ Não foram encontradas referências sobre Augusto Cesar Cruz.
} 
concepções de "pecado", "punição divina" " "natureza", embasadas numa moral "do certo e do errado" e repleta de eufemismos para expressar aquilo que era considerado tabu. (DALMOLIN, 2012, p. 7).

No caso específico do Mensageiro do Coração de Jesus, suas seções classificam-se entre aquelas que eram "fixas", as "esporádicas" e as "extraordinárias". Dentre as primeiras, é possível identificar: a "Intenção geral" do mês seguinte - dedicada a um pedido a Jesus Cristo, normalmente referente à evangelização; "Protestantismo Ilustrado" - que explanava os casos de indivíduos envolvidos com o Protestantismo e suas origens; "Discípulos do Coração de Jesus" - dedicada a explanar sobre a vida de pessoas que divulgaram o Sagrado Coração de Jesus, bem como a episódios da vida de Santos; "Movimento do Apostolado no Brasil" - que divulgava as notícias recentes nos apostolados de São Paulo, Rio de Janeiro, Bahia, Paraíba, Pernambuco, Porto Alegre e Pernambuco; "Notícias do Apostolado Estrangeiro" - com a divulgação de notícias de Apostolados Estrangeiros, como nos Estados Unidos, Polônia, Portugal e França; "Crônica Geral" - na qual eram comentadas notícias veiculadas por outros periódicos, que disessem respeito à Igreja Católica; "Revista dos interesses do S. Coração de Jesus" - contendo notícias referentes à Ordem do Sagrado Coração de Jesus nos territórios que em que este possuía adeptos, e "Graças alcançadas" - que veiculava as graças supostamente alcançadas pelos que acreditaram na religião.

Já as colunas esporádicas, configuravam em: "Poesia" - poemas destinados a figuras santas; "Leituras amenas" - dedicada às histórias que exaltassem as bençãos e graças alcançadas por aqueles que acreditavam e seguiam os mandamentos de Jesus; "Casos Edificantes" - responsável por apresentar casos de indivíduos que se converteram ao catolicismo, ou que seguiram os ensinamentos dessa religião, sendo estes enviados por leitores na maioria das vezes; "Fatos do Catolicismo" - destinado a veicular notícias religiosas sobre os locais em que o Catolicismo se fazia presente; "O Apostolado da Oração" - que veiculava notícias referentes ao Apostolado do Coração de Jesus.

Por outro lado, as colunas extraordinárias destinam-se à notícias especiais, como milagres ou celebrações religiosas. Essa configuração, segundo os próprios idealizadores do jornal, seria realizada com a inteção de possuir:

[...] matérias que podem servir para desenvolver a piedade, todos os deveres da perfeição cristã e religiosa, todos os interesses da Igreja e das almas, a doutrina católica toda, a história do passado, e os acontecimentos presentes, numa palavra, tudo o que pode interessar à 
um cristão, é tratado alternativamente nas páginas do Mensageiro. (MENSAGEIRO DO CORAÇÃO DE JESUS, tomo 1, n.6, 1896-1898, p. 301)

Na busca por criar a identidade do Mensageiro, seus editores definiram-no enquanto um periódico católico apresentado, na citação acima, como sinônimo de cristão. Para os editores, portanto, os cristãos eram os adeptos do catolicismo, demonstrando uma deslegitimação de quaisquer outras religiões cristãs. Nesse sentido, ser "cristão" dependeria, também, da observância de determinados hábitos, comportamentos e todo um sistema de crenças que o jornal se propunha a formar e modelar. Para alcançar tais objetivos, os assuntos tratados no periódico incluíam:

[...] um artigo sobre a intenção de cada mês abençoada pelo Santo Padre, escritos de assuntos doutrinais e instrutivos, não deixando, quando for possível, alguma parte literária e recreativa. Oferece especialmente notícias do movimento do Apostolado no Brasil e do mundo católico, assim também os avisos e comunicações desta Diretoria Central. Tem o seu redator principal [P. Bartolomeu Taddei] auxiliado por outros de reconhecido zelo pela santa causa. (MENSAGEIRO DO CORAÇÃO DE JESUS, tomo 1, n.1, 1896-1898, p. 7).

Além dos tópicos acima citados, também é possível verificar relatos de leitores que obtiveram sucesso em suas preces, além dos "casos edificantes", fundamentados em relatos de indivíduos considerados de grande status social, que se converteram ao catolicismo, tais como políticos ou pastores. Neste sentido, também no caso do Mensageiro do Coração de Jesus é possível identificar a estratégia comum a outros periódicos religiosos da época, conforme apontado por Stefano, segundo qual:

[...] ya no se trata de un periódico redactado por un único publicista, sino de una iniciativa celectiva, destinada a generar lazos perdurables entre hombres que han de comprometerse crecientemente con la desefa de los amenazados "derechos de la Igresia". Una Iglesia a la que ven con mucha más claridad, de manera mucho más concreta que sus ancestros, con una instituición de dimensón universal. El caráter coletivo de la empresa permite considerar sua aparición como una manifestación más de la “explosión associativa”. (DI STEFANO, 2015, p. 17) 
O Mensageiro do Coração de Jesus circula no Brasil até os dias atuais e sua distribuição é realizada nacionalmente através de assinaturas. $\mathrm{Na}$ interpretação coeva do próprio jornal: "Em todas as cidades do Brasil os Diretores e Zeladores do Apostolado estão autorizados a receber assinaturas e suas importâncias [...]. Para os Associados do Coração de Jesus é uma necessidade possuir esta revista." (MENSAGEIRO DO CORAÇÃO DE JESUS, tomo 1, n.11, 18961898, p. 568).

Nesse sentido, o periódico exerceu grande influência no culto ao Sagrado Coração de Jesus e na sociedade cristã da época, já que possuía circulação nacional. Sendo diretamente ligado à religião católica, observa-se que o mesmo pode ser analisado como uma maneira de:

[...] lançar mão do capital religioso na concorrência pelo monopólio da gestão de bens de salvação e do exercício legítimo do poder religioso enquanto poder de modificar em bases duradouras as representações e práticas dos leigos, inculcando-lhes um habitus religioso, objetivamente ajustado aos princípios de uma visão política do mundo social. (BOURDIEU, 1974, p. 57).

Nas próprias páginas do Mensageiro, observa-se a afirmação de que:

[...] Chegou este dia, em que o Apostolado do Coração de Jesus pode contar com seu órgão oficial. Todos os países possuem este auxílio tão poderoso de propaganda e conservação. Esta arma importantíssima e de grande alcance: não podia ficar mais tempo o Brasil desprovido dela. (MENSAGEIRO DO CORAÇÃO DE JESUS, tomo 1, n.1, 1896, p. 5).

Portanto, os próprios editores do jornal o consideram meio de difusão de determinados ideiais e, segundo os mesmos, um dos mais eficazes:

Gozando das mesmas vantagens do livro, e do opúsculo de propaganda religiosa, a revista dispõe ainda de uma grande vantagem sobre eles. Ela refere-nos todos os acontecimentos decorridos desde a publicação do seu 
último número e, de um modo especial, aqueles sucessos relativos à causa que advoga. Manifesta-nos os grandes esforços empregados na defesa e propagação da causa que abraçamos; apresenta-nos belos exemplos, próprios para nos servirem de estímulo e animação. (MENSAGEIRO DO CORAÇÃO DE JESUS, tomo 1, n.8, 1897, p. 449).

Tal "causa" fundamenta-se, essencialmente, em três pontos: defesa de uma moral específica; legitimação do catolicismo sobre o protestantismo e a crítica a determinados aspectos da modernidade. Entretanto, esta é defendida em partes, pois, ao mesmo tempo em que esses clérigos reivindicam a tradição religiosa - e criticam aspectos contrários a ela -, a educação e a autonomia da Igreja, observadas como agentes da civilização e do progresso, são reivindicadas.

Nesse sentido, o principal embate no Mensageiro realiza-se primeiramente contra o Estado laico e, em segundo lugar, contra o regalismo, que dificultariam a existência da tradição religiosa - observada por eles como a tradição provinda da Cúria Romana - de forma contínua. Incorporando algumas das teses do tradicionalismo católico de matriz francesa, ${ }^{11}$ seus editores procuravam, como estes teólogos e filósofos, "defender o homem para conquistar a sua liberdade perante o Estado, os outros homens e as paixões" (CORDI, 1984, p. 9). Sendo assim, o Estado deveria subordinar-se aos fins religiosos. O papa, por meio do dogma da infalibilidade, possuiria poder moral e religioso sobre todas as nações do mundo, favorecendo uma afinidade entre tradicionalismo e ultramontanismo, na qual o primeiro forneceria o aparato teórico para o segundo. Além disso, ambas as correntes defendiam a construção e manutenção de uma sociedade cujas estruturas fossem cristãs, por razão da fraqueza humana, sendo esta a única garantia de salvaçao ao povo (CORDI, 1984, p. 37-38).

Os tradicionalistas como os ultramontanos continuaram a defender uma
sociedade organizada hieraraquicamente e fundada sobre o privilégio,
religiosamente unida, na qual a fé católica era considerada sempre o
único fundamento do Estado, e os direitos políticos e civis eram
subordinados à fé, e à prática religiosa: uma sociedade confiada a uma
autoridade investida do alto, que exigia por isso uma obediência alheia
a qualquer crítica e na qual o altar e o trono, claramente distintos, seriam
estritamente ligados por uma identidade de fins e interesses, ou dito

${ }^{11}$ Corrente de pensamento que procura interpretar e modificar o mundo moderno como alternativa ortodoxa às mudanças institucionais e jurídicas do período pós-revolução francesa. Embora não houvesse uma plena coesão entre as teses tradicionalistas propagadas por intelectuais de diferentes tendências, é possível identificar um esforço comum por parte destes em "fundamentar teoricamente novas posições que valorizem os laços sociais ou outras dimensões de coesão social em oposição ao individualismo dissolvente dos iluministas" (CORDI, 1984, p. 38). 
explicitamente, onde o altar dominasse, religiosa e moralmente, o trono (CORDI, 1984, p. 38).

Entretanto, apesar desses pontos de afinidade, tradicionalismo e ultramontanismo se diferenciam. Enquanto o primeiro é uma corrente de pensamento que busca "interpretar e modificar o mundo moderno", o ultramontanismo é essencialmente um "esforço de sobrevivência de um grupo religioso institucionalizado que adota como estratégia fundamental encontrar uma nova forma de convivência com os governos em fase de laicização" (CORDI, 1984, p. 38-39). Sendo assim, os ultramontanos apropriaram-se de diferentes ideologias, filosofias e oportunidades históricas, não aceitando o tradicionalismo integralmente. ${ }^{12}$ No caso brasileiro, como em outras partes do mundo, os ultramontanos passaram a revitalizar o clero através da mudança de pessoas responsáveis pela imprensa, pelos educandários e indicando bispos fiéis nas dioceses mais importantes (CORDI, 1984, p. 43). Através destes instrumentos, produziram textos em que a história da humanidade era de luta entre o bem e o mal. Afirmavam que o bem só vigorara completamente sobre as forças do mal na Idade Média, quando os homens estavam totalmente submetidos à Igreja e viviam em concórdia (PINHEIRO, 2009, p.6).

Contra essa sociedade, voltara-se o demônio, representado pela maçonaria, pelos estados absolutistas que enfraqueceram o poder da Igreja, pelo Protestantismo, pelo humanismo, pelo naturalismo, pelos filósofos iluministas, pela Revolução Francesa, com as doutrinas da liberdade de culto, da secularização do ensino, da independência do poder civil. (PINHEIRO, 2009, p. 6)

Apesar da Companhia de Jesus não se configurar numa mera extensão do ultramontanismo, no caso específico dos jesuítas fixados em Itú, fora possível observar diversos pontos em comum com essa vertente do catolicismo. A crítica às novas tendências políticas desenvolvidas após a Revolução Francesa, a defesa do dogma da infalibilidade papal, a crítica ao processo de laicização da sociedade - principalmente em relação à educação - e à subordinação da Igreja ao Estado, conforme o modelo regalista, foram verificadas nos discursos veiculados pelo Mensageiro do Coração de Jesus, demonstrando sua coesão com os ideais ultramontanos.

\footnotetext{
${ }^{12}$ Dentre os intelectuais católicos europeus que assumiram posição ultramontana, destacam-se os franceses Joseph de Maistre (1753-1821), Félicité de Lamennais (1782-1854) e Louis Veuillot (1813-1883) e o espanhol Jaime Balmes (1810-1848).
} 
Sintetizados por Bartolomeu Taddei no folheto de "Homenagem ao Pontífice Pio X no seu jubileu sacerdotal", tais ideais foram balizadores da ação evangelizadora dos jesuítas estabelecidos em Itú:

\begin{abstract}
À medida que os inimigos da Igreja com os novos erros do "modernismo" se esforçam por despir a adorável pessoa de Jesus Cristo de todo o cárater divino: à medida que o grande Pontífice Pio IX, apoiado nas mãos do Jesus Redentor, se entrega ao penoro afã de organizar a sociedade prestes a dissolver-se, é mister proclamar bem alto [...] o reino do Coração de Jesus e a sua divindade ${ }^{13}$.
\end{abstract}

Assim como os clérigos de tendência ultramontana, os jesuítas analisados alinharam-se à defesa dessa tradição, perpassada pela necessidade de afirmação de uma moral específica fomentada pela Igreja. Esta, de forma ampla, buscará criar um habitus nos leitores do jornal, de modo a direcionar determinados tipos de ações e comportamentos. O divórcio, por exemplo, apresenta-se como uma questão a ser combatida:

Certos espíritos desequilibrados, servindo a paixões inconfessáveis, tem querido trazer para nosso querido Brasil a praga assoladora do divórcio. [...] A indissolubilidade do vínculo matrimonial é a salvaguarda da prosperidade e bem estar da família. É ela que cerra muitos males consequentes do divórcio. (MENSAGEIRO DO CORAÇÃO DE JESUS, tomo 4, n.40, 1899, p. 229).

Isso porque, afirmavam, nunca a ofensa a Deus teria sido tão "geral e provocadora da justiça" (MENSAGEIRO DO CORAÇÃO DE JESUS, tomo 1, n. 2, 1896, p. 52), e porque o "culto direto e positivo à Satanás é um fato de domínio público." (MENSAGEIRO DO CORAÇÃO DE JESUS, tomo 1, 1896, p. 53). E, para livrar-se dos pecados, era necessário realizar a penitência que "[...] segundo o Concílio de Trento [...] são os jejuns, as esmolas e as orações." (MENSAGEIRO DO CORAÇÃO DE JESUS, tomo 1, n.2, 1896, p. 55). A moral é tão importante à

\footnotetext{
${ }^{13}$ Manifestação solene promovida pelo apostolado da oração do brasil ao SSMO. Coração de Jesus em homenagem ao S. Pontífice Pio X no seu jubileu sacerdotal, 1868. Até o momento, o documento não está catalogado e se encontra disponível no Arquivo da Cúria Metropolitana de São Paulo.
} 
Igreja Católica, pois, na perspectiva apresentada, sem ela não seria possível realizar obras de expiação verdadeira (MENSAGEIRO DO CORAÇÃO DE JESUS, tomo 1, n.2, 1896, p. 54).

\begin{abstract}
Na Igreja, pois, encontram os homens o verdadeiro ensino da doutrina e moral de Cristo, os preceitos que ele formulou para regra de nossa conduta em todos os estados da vida, e os sacramentos, canais de graça, elementos essenciais de santificação. Todo aquele que deseja salvar sua alma tem de ouvir a Igreja e cumprir, como condição indispensável, a lei de Deus contida nos dez mandamentos da Antiga Lei, que Jesus Cristo confirmou, e os preceitos que ela impõe em nome do Divino Salvador. (MENSAGEIRO DO CORAÇÃO DE JESUS, tomo 1, n.7, 1896, p. 345).
\end{abstract}

O Padre, por sua vez, enquanto representante direto da palavra de Deus:

[...] tem nas mãos as esperanças do porvir e os germens da regeneração social, porque lhe foram confiada a pregação do Evangelho e a administração do sacramento. Não defende o Estado pelas armas, mas, soldado de Jesus Cristo, combate em prol da verdade, da ordem e da justiça, fundamento único da prosperidade das nações. (MENSAGEIRO DO CORAÇÃO DE JESUS, tomo 3, n.32, 1899, p. 481).

Pautados nesta defesa ortodoxa da moral cristã, os editores do Mensageiro deslegitimavam aqueles que se configuravam concorrente mais direto do catolicismo no campo religioso: os protestantes, considerados hereges (MENSAGEIRO DO CORAÇÃO DE JESUS, tomo 1, n.2, 1896, p. 79) e causadores de muitos males para a sociedade. Enquanto os padres apresentam-se como a "salvação" do mundo terreno, os protestantes eram associados a "homens miseráveis e sem caráter" no comando de suas Igrejas (MENSAGEIRO DO CORAÇÃO DE JESUS, tomo 1, n.11, 1897, p. 590.).

Buscando exercer tal persuasão através do Mensageiro, afirma-se nele que Lutero, "[...] com a iniqua e atrevida língua bem deixa ver o que tem no coração; e eu creio que ou ele delira, ou está entregue ao mau espírito que o governa." (MENSAGEIRO DO CORAÇÃO DE JESUS, tomo 1, n. 4, 1896, p. 195). Isso porque teria traído a "Mãe Igreja", transformando-se num "novo Judas" (MENSAGEIRO DO CORAÇÃO DE JESUS, tomo 1, n.12, 1897, p. 656). 
A reivindicação de crenças católicas para, inclusive, nomear a suposta traição de Lutero, também demonstra uma disputa pelos bens simbólicos, em torno dos mesmos significados e interpretação das Escrituras. Neste caso, a interpretação de Judas como traidor de Jesus. Por sua vez, além do campo moral, tal disputa pelos bens de salvação com os protestantes perpassa também o campo econômico, já que o Mensageiro busca, através de suas mensagens, interferir nos hábitos cotidianos mundanos, de seus leitores:

É triste ver católicos, e até padres e comunidades religiosas comprando diariamente em lojas de ímpios, declarados inimigos da Igreja, e assim subministrando-lhes o dinheiro com que ele fazer guerra à mesma Igreja. Quantos jornais perversos não acabariam por falta de recursos com a retirada dos assinantes católicos. (MENSAGEIRO DO CORAÇÃO DE JESUS, tomo 4, n.39, 1899, p. 155).

Naquela conjuntura em que as relações entre Igreja Católica e Estado brasileiro reconfiguravam-se, ambas as denominações cristãs buscavam definir suas identidades próprias e, para tanto, era necessário que se fortalecessem perante e através da sociedade. Por isso a preocupação com a educação, responsável pela formação dos indivíduos e de seus esquemas de pensamento. Numa crítica ao modelo de Estado laico, bem como à forte influência do protestantismo nesta esfera da sociedade (um de seus principais instrumentos de divulação), o Mensageiro anunciava que: "O lar doméstico e as escolas são, na hora presente, o campo aberto onde se trava a grande batalha que deve decidir o futuro dos povos cristãos" (MENSAGEIRO DO CORAÇÃO DE JESUS, tomo 3, n. 30, 1898, p. 294). Dssa forma, a atuação dos clérigos em relação à educação seria a de "[...] combater eficazmente a deplorável influência das escolas sem Deus, salvaguardar a inocência dos meninos e preparar uma mocidade cristã." (MENSAGEIRO DO CORAÇÃO DE JESUS, tomo 3, n.33, 1898, p. 720). Esta, só existiria através de um ensino religioso, que se configuraria num:

[...] ensino histórico, apologético, moral em que se adquirem armas para combater os inimigos ousados do Catolicismo; sim, ousados, mas não profundos, fracos a qualquer rebate decidido e firme. [...] [os moços] [...] levam o cabedal da ciência verdadeira para se premunirem contra a falsa ciência; eles saem dos colégios, onde se adquirem também proficuamente a ciência humana, convencidos da perfeita harmonia que existe entre a fé e a razão, e não se deixarão facilmente imbuir pelo 
charlatanismo da moderna ciência. (MENSAGEIRO DO CORAÇÃO DE JESUS, tomo 2, n.16, 1897, p. 173)

Buscando adaptar-se à conjuntura moderna, mas, ao mesmo tempo, manter sua legitimidade e tradição perante ela, os jesuítas aqui estudas revelaram uma relação paradoxal com as tendências em voga. Também neste aspecto, revelaram afinidades importantes com a tendência ultramontana, cuja legitimidade política e moral exigia uma identificação com os "ideias de modernização da sociedade, próprias do projeto de romanização, marcando um exemplo do poder de articulação da hierarquia eclesiástica" (TAVARES, 2006, p. 1). Na análise de seus argumentos, é possível identificar como o alvo principal de suas críticas aquilo que era compreendido como uma modernidade essencialmente racionalista, o que, no trecho acima estacado, levava à oposição de uma ciência moderna associada a "charlatanismo", à "verdadeira ciência", capaz de promover a harmonia entre fé e razão.

Por outro lado, utilizou-se da defesa da Pátria, associada ao referencial político do Estado nacional moderno, para defender o ensino religioso, um dos meios mais eficazes e tradicionais de manutenção da legitimidade católica. Exemplo disso se faz quando os jesuítas editores do Mensageiro do Coração de Jesus e, concomitantemente, professores do Colégio São Luís afirmavam que:

[...] a educação religiosa, dada por padres e jesuítas, não abafa os sentimentos de amor à pátria terrena na contemplação celeste; e, mesmo longe dela, se afervora, ao contato da fé; ao mesmo que tempo que cresce o amor para com a Religião. (MENSAGEIRO DO CORAÇÃO DE JESUS, tomo 2, n.16, 1897, p. 218).

Nesse sentido, o ensino religioso não seria contra a pátria terrena, mas antes serviria como seu fundamento, subordinando-a à "pátria divina". Justamente devido a tal subordinação, o ensino deveria permanecer a cargo da Igreja:

O concurso para o ensino religioso, pelo modo que estiver ao alcance de cada um, se impõe atualmente como um dever a todos os bons e decididos católicos. Temos a obrigação de dar um remedio na medida de nossas forças, às odiosas manobras, com que ferem e matam tantas 
almas de meninos. (MENSAGEIRO DO CORAÇÃO DE JESUS, tomo 1, n.6, 1896, p. 239).

Sobre esta questão, afirma-se ainda que:

Ora, considerado em si mesmo, o Estado não pode sujeitar ao seu domínio nem o ensino, nem a educação, quer consideremos o homem (como os liberais) na ordem natural, quer na sobrenatural, segundo a crença católica. No primeiro caso, a educação e o ensino por direito natural pertencem ao domínio dos pais de família. No segundo caso, pertence à Igreja por direito divino: o Estado, longe de poder diminuir a liberdade dos pais e da Igreja, a deve tutelar. (MENSAGEIRO DO CORAÇÃO DE JESUS, tomo 4, n.44, 1900, p. 490).

Na visão do jornal, por sua vez, a permanência do ensino religioso era justificada não apenas em função dos interesses da Pátria, sociedade e almas dos indivíduos, mas, da confirmação dos ideais trazidos pela própria modernidade, já que:

Os modernos reformadores e revolucionários falam sempre em liberdade, mas, de fato, professam mais o atróz despotismo; e conquanto reconheça a liberdade de ensino, por uma consequencia lógica da liberdade do pensamento, como tudo hoje querem sujeitar o ensino à virga férrea dos governos ímpios, excluindo dele os representantes da Igreja e procurando por vários modos roubar a juventude à direção e influência da Igreja. (MENSAGEIRO DO CORAÇÃO DE JESUS, tomo 4, n.44, 1900, p. 489).

Assim, através dos próprios ideais modernos, a Igreja criticava a modernidade. ${ }^{14}$ Mas, ao criticá-la, utilizava-se dos novos meios inaugurados, bem como de argumentos modernos

\footnotetext{
${ }^{14}$ Apesar de suas diversas facetas, entende-se como modernidade o período histórico pós Revolução Francesa no qual a razão estabeleceu-se de forma autônoma na construção do conhecimento por meio dos ideiais iluministas, quebrando o monopólio dos preceitos teológicos. Nessa nova configuração os indivíduos menos influenciados por costumes e crenças tradicionais são governados por Estados modernos que não dependem da igreja para legitimar-se. Essa configuração laica
} 
para manter a tradição. Tal relação paradoxal entre tradição, modernidade, secularização e catolicismo, se justifica, segundo Berger, pois:

O indivíduo moderno existe numa pluralidade de mundos migrando de um lado a outro entre estruturas de plausibilidade rivais e muitas vezes contraditórias, cada uma sendo enfraquecida pelo simples fato de sua coexistência involuntária com outras estruturas de plausibilidade. (BERGUER, 1997, p. 78-79).

Nesse sentido, tais estruturas que conferem a base social para a conservação da realidade existem concomitantemente, não possibilitando a interpretação do discurso religioso aqui analisado, e as tendências em voga, que acenavam com diferentes projetos e concepções de modernidade, de forma hegemonicamente conflitante ou totalmente independente. Exemplo disso é que a própria difusão da imprensa, associada a uma das novidades que marca a modernidade ocidental, serviu a diferentes propósitos. Como aponta Di Stefano, referindo-se ao caso argentino:

[...] no se piensa la revista primordialmente como un arma controversial (aunque en algunos momentos lo sería), sino como el órgano de los intereses religiosos del país, como tantos otros lo son de sus intereses políticos e sociales. (DI STEFANO, 2015, p. 15)

\section{Conclusão}

Mediante a concorrência entre diferentes projetos e modelos de relacionamento entre Igreja e Estado, no Brasil da segunda metade do século XIX, e da acelerada expansão dos confrontantes do catolicismo - representados pelo "vendaval das liberdades modernas' que começava a açoitar o Brasil" (CIARALLO, 2011, p. 93) o núcleo jesuíta instalado na então Vila de Itú precisaram valer-se de diferentes estratégias e articulações simbólicas e materiais, a fim de garantirem sua sobrevivência enquanto grupo religioso institucionalizado. Neste sentido,

gera o pluralismo religioso (BERGER, 1985, p. 139), salientando que apesar do processo de secularização, as concepções religiosas não se extinguiram nas sociedades modernas. 
embora pautando-se em princípios próprios à Ordem a qual pertenciam, aproximaram-se das tendências ultramontanas em voga, reabilitando no plano discursivo matrizes teológicas, filosóficas e políticas que pautaram uma dada visão de mundo e de sociedade perfeita, bem como dos ideais de progresso e civilização, os quais não puderam dispensar neste processo de reordenamento dos padrões de relacionamento entre Igreja, Estado e Sociedade.

Uma dinâmica que esgarça um momento específico da secularização no Brasil, aqui concebida como processo histórico, que implica a "reorganização permanente da religião" (HERVIEU-LÉGER, 2004), implicando que instrumentos essencialmente modernos, utilizados pelos setores seculares acusados como "inimigos da Igreja", fossem apropriados como veículo privilegiado na propagação de determinadas concepções e esquemas de pensamento, muitas vezes contrários a aspectos específicos da própria modernidade.

Esta a dinâmica que se procurou identificar nas páginas do periódico $O$ Mensageiro do Coração de Jesus, mas que, conforme frisamos, reflete uma tendência mais geral da imprensa ultramontana do período em questão. Criticando e ao mesmo tempo reivndicando determinados referenciais vigentes, formularam uma crítica contundente à sociedade laica e, particularmente, ao que associavam à origem de "todas as maldades e crimes", oriundos, segundo o Mensageiro, dos "princípios de 1789 e da Revolução Francesa" (MENSAGEIRO DO CORAÇÃO DE JESUS, tomo V, n.49, 1900, p. 35).

Neste sentido, o modelo de Estado laico articuladamente ao anticlericalismo desta Revolução, constituíam o núcleo duro das críticas tecidas pelo periódico. O projeto de modernidade que em suas páginas combatia era aquele apresentado como sinônimo de ideias anti-cristãs - que teriam sido "espalhadas pelos grandes poetas e filósofos", e no Brasil, pela "burguesia maçonizada" (MENSAGEIRO DO CORAÇÃO DE JESUS, tomo 2, n.24, 1898, pp. 671672). Denunciavam, assim, o "supremo erro de nossos legisladores, quando afastaram de nossas escolas, nossas famílias, de nossos tribuinais, da nossa sociedade nosso berço e de nossa sepultura a Providência de Deus". (MENSAGEIRO DO CORAÇÃO DE JESUS, tomo 2, n.20, 1898, pp. 464-465).

Ao criticarem o modelo de Estado laico, por sua vez, os clérigos jesuítas responsáveis pelo jornal contribuíram para barrar as condições, jurídicas e institucionais, do pluralismo religioso no Brasil, o qual construiu-se não resultou "da conflituosa convivência de diversas confissões religiosas preexistentes à constituição do Estado republicano" laico, mas, inversamente, configurou-se em produto histórico deste mesmo processo, pautado em critérios socialmente hegemônicos e politicamente legitimados sobre o que se concebia como "religião" (MONTERO, 2009, p. 10).

De mesma forma, os discursos impressos nas páginas do Mensageiro do Coração de Jesus, nos permitem apurar a natureza das relações conflitivas entre religião e política, neste percurso específico da secularização no Brasil. Especificamente, a defesa da infalibilidade 
papal demonstra como o periódico se alinha às disputas entre Estado e Igreja católica, acirradas, sobretudo, após a "Questão Religiosa", entre 1872 e $1875 .{ }^{15}$ Na Seção denominada "Crônica Geral", por exemplo, um dos tópicos faz referência à "Independência do Papa", afirmando que "[...] Consideramos a Independência da Santa Sé como interesse religioso e social de primeira ordem, e entendemos que só na soberania há verdadeira independência". (MENSAGEIRO DO CORAÇÃO DE JESUS, tomo 1, n.1, 1896, p. 45).

Além de estar fundamentada no "poder que Jesus Cristo recebeu do seu Eterno Padre, o transmitiu a S. Pedro e seus sucessores; por consequência ao Sumo Pontífice" (MENSAGEIRO DO CORAÇÃO DE JESUS, tomo 1, n.12, 1897, p. 625), valiam-se da constatação histórica específica à conjuntura brasileira - mas que encontrava respaldo no processo mais amplo conhecido como romanização das Igrejas católicas em todo o mundo -, segundo a qual, no último quarto do século XIX haveria uma tendência pronunciada para o "reflorescimento da fé", através da nomeação dos bispos Antônio Joaquimde Mello, Lino Deodato Rodrigues de Carvalho, e o bispo diocesano Joaquim Arcoverde, além da companhia de Jesus no ensino e nas missões e a Congregação das Irmãs de São José com seus colégios (MENSAGEIRO DO CORAÇÃO DE JESUS, tomo 1, n.2, 1896, p. 48).

Tais atores eram apresentados como braços do ultramontanismo no Brasil e, nesse sentido, objetivava-se que Roma fosse "o modelo e o espelho de todo mundo". (MENSAGEIRO DO CORAÇÃO DE JESUS, tomo 3, n.32, 1899, p. 421), em detrimento dos poderes das Igrejas nacionais, conforme era defendido pelo modelo regalista, hegemônico na primeira metade do século. Nessa conjuntura, mesmo quando as solicitações enviadas pelos clérigos fixados em Itú ao Papa eram negadas, observa-se a construção de um discurso que enaltece e reafirma a infalibilidade papal, deixando clara a proximidade ideológica com as tendências ultramontanas assumidas por estes jesuítas:

Foi meu pensamento celebrar a festa com a coroação da imagem, que se venera no Santuário. Fiz chegar, para este fim, aos pés do SS. Padre uma humilde petição. S. Santidade, porém, ainda que disposto a enriquecer o Santuário Central dos maiores favores espirituais, em sua alta sabedoria julgou não dever aceder a essa piedos aspiração. Com o mais profundo acatamento recebemos todos a decisão do Vigário de Jesus Cristo, que do alto da Cadeira de S. Pedro abrange seu olhar iluminado a Igreja

\footnotetext{
${ }^{15}$ A Questão Religiosa foi aberta pela condenação imposta ao padre José Luís de Almeida Martins pelo bispo D. Pedro Maria de Lacerda, em represália ao fato daquele ter discursado na comemoração da Lei do Ventre Livre, organizada pela loja Maçônica Grande Oriente do Lavradio, em homenagem ao Visconde do Rio Branco, grão-mestre maçom e Presidente do Conselho de Ministros do Império. Esta decisão foi apoiada pelos bispos do Pará - D. Macedo Costa - e a diocese de Pernambuco - D. Vital - que em cumprimento às decisões pontifícias que condenavam a maçonaria, "requereram que as irmandades retirassem do seu grêmio os membros que pertenciam a dita sociedade secreta". As confrarias que se recusaram a cumprir tal determinação apresentaram um "recurso à Coroa", que foi acatado, episódio do qual resultou a condenação e prisão dos referidos bispos, anistiados em 1875. (SANTIROCCHI, 2015, p. 14-15)
} 
Universal e, melhor que ninguém, percebe o que exigem os interesses da fé, na hora presente. [...] Esta grande manifestação tem por efeito significar que os católicos do Brasil aclamam com todo entusiasmo o reinado do Coração de Jesus e renovam intera submissão ao seu representante na terra: tem por efeito significar para o exército Divino Rei o sinal do combate. (MANIFESTAÇÃO SOLENE, s.d.) $)^{16}$

Desse modo, através do conteúdo veiculado em suas páginas é possível concluir que o Mensageiro do Coração de Jesus, inicialmente um jornal de cunho religioso, demonstra aspectos importantes para a análise da sociedade da epóca, bem como sobre os debates em torno dos novos modlos de relacionamente entre Igreja e Estado no Brasil.estavam em voga naquele momento.

\section{Referências}

ANDERSON, Benedict. Comunidades imaginadas. São Paulo: Cia das Letras, 1989.

ARDUINI, Guilherme; SILVEIRA, Diego. Valores, normas e crenças: uma leitura das linguagens políticas conservadoras nos periódicos a ordem (Rio de Janeiro) e o arquidiocesano (Minas Gerais). In: RODRIGO, Cândido et al. (Org.). Manifestações do pensamento católico na américa do sul. São Paulo: Fonte Editorial, 2015. p. 155-177.

BERGER, Peter. O dossel sagrado: elementos para uma teoria sociológica da religião. São Paulo: Paulinas, 1985.

BERGUER, Peter. Rumor de anjos: a sociedade moderna e a redescoberta do sobrenatural. Petrópolis: Vozes, 1997.

BOURDIEU, Pierre. A economia das trocas simbólicas. São Paulo: Perspectiva, 1974.

CAPELATO, Maria. Imprensa e história do Brasil. São Paulo: Contexto/EDUSP, 1988.

CASANOVA, José. Rethinking secularization: a global comparative perspective. The Hedgehog Review, Charlottesville, v. 8, n. 2, p. 7-22, 2006.

\footnotetext{
${ }^{16}$ Apesar de não ser datado, o documento faz referência à data de 16 agosto, domingo. Considerando o período do papado de Pio X (1903-1914), inferimos que o documento seja de 1903.
} 
CIARALLO, G. O tema da liberdade religiosa na política brasileira no século XIX: uma via para a compreensão da secularização da esfera política. Sociologia Política, Curitiba, v. 19, n. 3, p. 8599, fev. 2011.

CORDI, Cassiano. O tradicionalismo na república velha. 1984. 188 f. Tese (Doutorado em Filosofia) - Universidade Gama Filho, Rio de Janeiro, 1984.

DALMOLIN, Aline. Por uma história da imprensa católica brasileira. In: ENCONTRO DO NÚCLEO GAÚCHO DE HISTÓRIA DA MÍDIA, 4., 2012, São Borja. Anais... São Borja, 2012.

DI STEFANO, Roberto. "Por una historia de la secularización y de la laicidad en la Argentina". Quinto Sol. vol. 15, n. 1, 2011, p. 1-32.

DI STEFANO, Roberto. "La revista La Relijion (1853-1862) y la formación de un círculo intelectual ultramontano en buenos aires', in: CALDEIRA, Rodrigo Coppe; et. alli (orgs.). Manifestações do Pensamento Católico na América do Sul. São Paulo: Fonte Editorial, 2015, pp. 15 $-41$.

DI STEFANO, Roberto. Disidencia religiosa y secularización en el siglo XIX iberoamericano: cuestiones conceptuales y metodológicas. Projeto História, São Paulo, n. 37, p. 157-178, dez. 2008.

GRESCHAT, Hans Jurgen. O que é ciência da religião. São Paulo: Paulinas, 2005.

HAUPT, Heinz-Gerhard. Religião e nação na Europa no século XIX: algumas notas comparativas. Estudos Avançados, São Paulo, v. 22, n. 62, p. 77-94, 2008.

HERVIEU LÉGER, Daniéle. La modernité rituelle: rites politiques et religieux des sociétés modernes. Paris: 1'Harmattan, 2004.

JULIA, Dominique. História religiosa. In: LE GOFF, Jacques; NORA, Pierre (Org.). História: novas abordagens. Rio de Janeiro: Francisco Alves, 1976. p. 106-131.

LONDOÑO, Fernando. História das religiões. In: PASSOS, João Décio; USARSKI, Frank. (Org.). Compêndio de ciência da religião. São Paulo: Paulus, 2013.

MADUREIRA, I. A liberdade dos índios, a Companhia de Jesus: sua pedagogia e seus resultados. Rio de janeiro: Imprensa Nacional, 1927.

TADDEI, Bartholomeu, Manifestação Solene promovida pelo Apostolado da Oração do Brasil ao SSMO Coração de Jesus, em homenagem ao Sumo Pontífice Pio X em seu Jubileu Sacerdotal. Itú, s.d.

MARTINS, Patrícia Carla de Melo. Padroado Régio no auge do Império Brasileiro. Revista Brasileira de História das Religiões, Maringá, ano 3, n. 9, jan. 2011. 
MENSAGEIRO DO CORAÇÃO DE JESUS. 1896-1900. Disponível em: <http://www.mensageirodosagradocoracao.com.br/revista.asp.>. Acesso em: 24 jun. 2016.

MONTERO, Paula. Secularização e espaço público: a reinvenção do pluralismo religioso no Brasil. Etnográfica, Lisboa, v. 13, n. 1, p. 7-16, 2009.

MOREL, M. Os primeiros passos da palavra impressa. In: DE LUCA, Tania Regina; MARTINS, Ana Luiza (Org.). História da imprensa no Brasil. São Paulo: Contexto, 2008.

MOREL, Marco; BARROS, Mariana. Palavra, imagem e poder: o surgimento da imprensa no Brasil do século XIX. Rio de Janeiro: DP\&A, 2003.

ORLANDI, Eni Pulcinelli. A linguagem e seu funcionamento: as formas do discurso. São Paulo: Brasiliense, 1983.

PAULA, Eurípedes Simões. Trabalho livre e trabalho escravo. São Paulo, 1973.

PETERS, José Leandro. A história das religiões no contexto da história cultural. Faces de Clio, Juiz de Fora, v. 1, n. 1, jan./jun. 2015.

PINHEIRO, Alceste. O apóstolo, ano I: a autocompreensão de um jornal católico no século XIX. In: CONGRESSO DE CIÊNCIAS DA COMUNICAÇÃO NA REGIÃO SUDESTE, 14., 2009, Rio de Janeiro. Anais... Rio de Janeiro, 2009.

PIRES, Thiago. Revisitando a historiografia eclesiástica: a superação de uma narrativa eusebiana. In: BUARQUE, Virgínia A. Castro (Org.). História da historiografia religiosa. Ouro Preto: EDUFOP/PPGHIS, 2012. p. 27-42.

PRODI, Paolo. Il paradigma tridentino, un'epoca della storia della Chiesa. Brescia: Morcelliana, 2010.

RÉMOND, René. O retorno do político. In: CHAVEAU, A.; TÉTARD, Ph. (Org.). Questões para a história do presente. Bauru: EDUSC, 1999.

SANTIROCCHI, Ítalo D. Questão de consciência: os ultramontanos no Brasil e o regalismo do segundo reinado (1840-1889). Belo Horizonte: Fino Traço, 2015.

SANTIROCCHI, Ítalo D. Uma questão de revisão de conceitos: Romanização, ultramontanismo, reforma. Temporalidade, v. 2, n. 2, ago./dez. 2010, p. 24-33.

SCHEWENGBER, Otmar Jacob. Apostolado da oração e MEJ em perguntas e respostas. São Paulo: Loyola, 2014. 
SILVA, Ana Rosa Cloclet da; LOURENÇO, Laís da Silva. Entre a política e a religião: uma análise da imprensa periódica feijoísta, na conjuntura de 1834 à 1835. Revista Brasileira de História das Religiões, Maringá, ano 7, n. 21, jan./abr. 2015. Disponível em: $<$ http://periodicos.uem.br/ojs/index.php/RbhrAnpuh/article/view/25688/15660>. Acesso em: 24 set. 2016.

SODRÉ, Nelson. A história da imprensa no Brasil. Rio de Janeiro: Civilização Brasileira, 1966.

SOUZA, Françoise Jean de Oliveira. Do altar à tribuna: os padres políticos na formação do estado nacional brasileiro. Rio de Janeiro, 2010.

TAVARES, Mauro Dillmann. Progresso e civilização à luz ultramontana: jornais católicos no Sul do Brasil - Porto Alegre, século 19. Revista História, São Paulo: Arquivo do Estado de São Paulo, n. 12, 2006.

Recebido em 21/03/2018

Aprovado em 16/05/2018 